\title{
Impact of Vocational Training on Wages of Ethnic Minority Labors in Vietnam*
}

\author{
Ha Thi Hai DO ${ }^{1}$, Cuong Ngoc MAI ${ }^{2}$, Anh Ngoc MAI ${ }^{3}$, Nui Dang NGUYEN ${ }^{4}$, Toan Ngoc PHAM ${ }^{5}$ \\ Huong Thi Thu LE', Manh Dung TRAN7, Tri Tuan VU ${ }^{8}$
}

Received: April 10, 2020 Revised: April 25, 2020 Accepted: May 07, 2020

\begin{abstract}
This research investigates the impact of vocational training on wages of ethnic minority labors in emerging countries; Vietnam is the case study. The study uses secondary data from 2014 to 2018 collected through Vietnam Household Living Standards Surveys (VHLSS) conducted by the General Statistics Office. In order to analyze the impact of vocational training on wages of ethnic minority areas in Vietnam, this research creates ethnic area variables. According to Vietnamese regulations, ethnic areas are communes of 51 different provinces, inhabited by ethnic minority people. The statistics from VHLSS in 2018, show that the proportion of labors of working age with a certificate was $22.5 \%$. The research employs Heckman Sample Selection Model to estimate the impact of vocation training on wage of labors in ethnic minority areas. The results show that vocational training plays a crucial role in improving the wages of ethnic minorities and has a positive impact. However, apart from the achieved outcomes, vocational training and job creation for ethnic minorities are not without limitations and shortcomings. Based on the findings, some recommendations to ethnic minority labors, enterprises and the Government are proposed to encourage participation in vocational training for the purpose of promoting the efficiency of the labor market.
\end{abstract}

Keywords : Ethnic Minorities, Vocational Training, Wage, Vietnam

JEL Classification Code: I28, I29, J15, J31

\section{Introduction}

*This research is one of the outcomes of a broader research project coded CTDT.26.17/16-20 funded by the National Science and Technology Program for the period 2016-2020 "Basic and urgent issues on ethnic minorities and ethnic policy in Vietnam until 2030".

${ }^{1}$ First Author and Corresponding Author. Dean, Faculty of Management Science, National Economics University, Vietnam [Postal Address: 207 Giai Phong Street, Dong Tam Ward, Hai Ba Trung District, Hanoi, 112456, Vietnam] Email: hadh@neu.edu.vn ${ }^{2}$ Counselor, Journal of Economics and Development, National Economics University, Vietnam. Email: cuongmn@neu.edu.vn

${ }^{3}$ Associate Dean, Faculty of Management Science, National Economics University, Vietnam. Email: maingocanh@neu.edu.vn

${ }^{4}$ Deputy Head of Department, Social Management Department, Faculty of Management Science, National Economics University, Vietnam, Email: nuind@neu.edu.vn

${ }^{5}$ Director, Centre for Information, Strategic Analysis and Forecast, Institute of Labor Science and Social Affairs, Vietnam. Email: toanpn@ilssa.org.vn

'Lecturer, Social Management Department, Faculty of Management Science, National Economics University, Vietnam. Email: thuhuong@neu.edu.vn

${ }^{7}$ Associate Editor, Journal of Economics and Development, National Economics University, Vietnam. Email: manhdung@ktpt.edu.vn
Ethnic minority groups normally have disadvantageous geographical and economic conditions, and hence, the labor force in these groups tend to face more difficulties in the labor market. Specifically, ethnic minorities have an inferior academic background. They mainly find employment in simple, low-skilled jobs that are not only underpaid, but also unstable and unsustainable. In the context of automation and technology changes in the world economy, and Vietnam economy as well, it is said that educational and technological skills must be advanced to succeed, which creates even more challenges to ethnic minority groups.

Training in general and vocational training in particular play an important part in improving job opportunities and wage for workers in ethnic minority groups. In Vietnam, the percentage of ethnic minority workers in vocational training

${ }^{8}$ Lecturer, Economic Management Department, Faculty of Management Science, National Economics University, Vietnam. Email: tuanvu@neu.edu.vn

(c) Copyright: The Author(s)

This is an Open Access article distributed under the terms of the Creative Commons Attribution Non-Commercial License (http://Creativecommons.org/licenses/by-nc/4.0/) which permits unrestricted noncommercial use, distribution, and reproduction in any medium, provided the original work is properly cited. 
(at elementary, intermediary and college level) is still low at $13.7 \%$. Vocational students are largely from rural areas, which accounts for up to $80 \%$; most of them are male (nearly $93 \%)$ and in young age group $(70.5 \%)$.

Ethnic minority workers need to be equipped with skills and proper technical knowledge in order to expand their job opportunities in either engineering, management or handmade fields. In addition, employed workers need training supports in order to have more stable careers and higher wages. This study aims to add a novel perspective as it looks into the impact of vocational training on wages of ethnic minority groups in Vietnam. The following questions have been raised to perform systematic review: Do trained vocational workers from ethnic minority groups witnessed improvement in terms of wages? Is there a gender difference in wages among these workers? In order to address these questions, this research employs Heckman Selection analytical method. It also makes use of the research data of Vietnam Household Living Standards Surveys (VHLSS) from 2014 to 2018.

\section{Literature Review}

According to Becker (1964) and Mincer (1974), the variation in salary among worker groups can be explained by the gap in human capital as well as skills acquired from experience and continuous vocational training. Ashenfelter, Harmon and Oosterbeek (1999) provide a comprehensive review of previous estimates of the rate of return to investment in schooling using a data set obtained from 27 studies and compare the different estimating methods. They find an average return of $6 \%$ to $7 \%$ when the ordinary least squares (OLS) method is used, and $9 \%$ when the instrumental variable (IV) method (also known as twin study method) is employed. They conclude that schooling investments have substantial economic payoff. Moreover, schooling and earnings have no causal relationship, but their correlation may cover the correlation between other determinants, e.g., earnings and ability. Trostel, Walker and Wolley (2002) notice a worldwide average rate of return to schooling investments of just under $5 \%$ for men and a little under $6 \%$ for women, with a great deal of variation across countries. Such a rate is lower than that reported by Ashenfelter et al. (1999). Trostel et al. (2002) also observe that the IV estimates are over $20 \%$ higher as compared to the OLS estimates. According to Heckman (1999), training after entering the labor force is a key part of investment in human capital. If investment bears fruit, salary and wage will be higher than direct and indirect costs of training. Investment in human capital can be from employers, workers or both. Training can boost productivity of workers, and consequently, lead to an increase in their salaries (Lynch, 1992; Blundell, Dearden, Meghir \& Sianesi, 1999). By using the data set from the 2008-2016 survey of Vietnamese living standards as well as other macroeconomic data, Nguyen, Nguyen, Nguyen, and Nguyen (2020) has proved that the high ratio of education leads to a higher level of inequality of income since the urban areas are home to well-educated people to live and work.

Jacobson, LaLonde and Sullivan (2005) analyze earnings from a professional education for displaced people. In the long term, earnings increase, on average, by $9 \%$ for males and $13 \%$ for females. Substantial differences are also found among different kinds of education. For example, earnings increase by $14 \%$ for males and by $29 \%$ for females with education in technical professions, whereas earnings are low for those educated in non-technical professions. For some courses, earnings are equal to zero. One-third of earnings is attributed to increased wages per hour, whereas the rest is attributed to an increased number of hours at work, indicating a return to schooling of about $3 \%$ to $5 \%$. On the other hand, while studying gender differences in earnings, Anel and Azimkhan (2019) point out women's wages in Kazakhstan are on average $30 \%$ of men's wages and confirm that gender discrimination in employment is the most important factor in the existing gender wage differences.

Hujer, Thomsen and Zeiss (2006) report a significant negative effect of vocational education and training (VET) on the duration of unemployment in Eastern Germany and investigate possible locking-in effects. The rationale for this is that the program content taught to participants is not in line with the market demand. In Andren and Andren (2006), one-factor control function estimator is used to allow for unobserved heterogeneity with factor-loading technique. They compare matching estimators and indicate that unobserved heterogeneity slightly increases the treatment effects of VET.

Oosterbeek and Webbink (2007) evaluate the long-term effects of an extra year of VET on wages in the Netherlands by using a control group of graduates from VET, the length of which did not change. They observe that an extra year of VET comes at the cost of a year less in work experience, and thus, has no benefit in terms of later wages. Bartlett (2009) confirms the view that vocational school systems should be strengthened, and abandoning VET would worsen the labor market outcomes especially for disadvantaged young people. Nguyen and Nguyen (2019) recommend that local vocational training centers should provide occupational training programs for the Khmer ethnic people to help them actively participate in doing business and create income-generating activities.

In 'transition economies', returns to VET are higher than returns to general education. There is also strong evidence from the United States that VET can provide special benefit to individuals with reduced abilities. Stromback (2010) uses single and multiple treatment effect approaches to compare the effects of two main educational choices: undertaking a VET qualification and/or completing Year 12. Using matching methods to estimate these effects, Stromback finds 
that neither completion of Year 12 nor a VET qualification has an effect on early career earnings over and above the previous experience. Although the findings do not deny the occurrence of a substantial return to schooling and VET, he suggests that the return is not a short time coming.

Choi (2016) assesses the positive impact of wage on skilled workers in the Philippines by using the Mincerian earnings function. He observes that the return on revenue (ROR) for VET after high school is dependent on the vocational education duration. It, however, can be superior to the ROR of general education. Besides, VET also provides employment opportunities to individuals, create skilled labor force and subsequently, enhancing the firm productivity.

Meer (2007) finds that there is a positive effect on wage from vocational training. Higher wage gained from academic education is also confirmed by Dearden, McIntosh, Myck, and Vignoles (2002). However, it is reported that the majority of vocational training programs increase wage based on professional level of workers.

Maliranta, Rouvinen and Ylä-Anttila (2010) highlight the importance of providing capabilities for employability as the student characteristics and performance has a crucial role in estimating their outcomes. For this reason, the education policy should be complemented with employment and regional policy. The importance of vocational training in explaining productivity growth is also illustrated in a recent study by Sala and Silva (2013). The results of a study by Tansel and Bodur (2012), based on quantile regression techniques, suggest that the per year returns to vocational high school ranged from $8.3 \%$ to $10.9 \%$. However, such an analysis does not control the ability of the individuals.

\section{Research Methodology}

\subsection{Empirical Model, Samples, and Variables}

Mincer equation is a single-equation model basing on human capital theory that has been widely exploited to explain earnings as a function of experience, schooling and experienced squared (Mincer, 1993):

$\operatorname{LnY}_{i}=\beta_{0}+\beta_{1} S_{i}+\beta_{2} E_{i}+\beta 3 E_{i}^{2}+e_{i}$

Where:

$\mathrm{LnY}_{\mathrm{i}}$ is the natural logarithm of wage $\mathrm{Y}_{\mathrm{i}}$;

$\mathrm{S}_{\mathrm{i}}$ is years of schooling;

EX is years of experience;

$\beta_{0}$ is a constant;

The error term is labeled as $e_{i} \sim \mathrm{N}\left(0, \sigma^{2}\right)$.

Squared experience $\left(\mathrm{EX}^{2}\right)$ is used to calculate the correlation between wage and experience yet descending.

In the standard Mincer equation, the speed of increase in wage following experience reflects the benefits to the worker generated from human capital investment and seniority (Franz, 2003). Mincer (1993) states that the human capital earnings function contains, among other variables, years of (work) experience, which enters in a nonlinear fashion. Its coefficients are interpretable as post-school human capital investment parameters. This implies that post-school human capital investments are dependent on work experience and can be treated as a black box. In order to open the black box, a dummy variable $\mathrm{T}$, indicating the participation in continuing vocational training, should be considered as an additional explanatory factor for earnings. Equation (1) is then rewritten as:

$$
\mathrm{LnY}_{\mathrm{i}}=\beta_{0}+\alpha \mathrm{T}+\beta_{1} \mathrm{~S}_{\mathrm{i}}+\beta_{2} \mathrm{EX}_{\mathrm{i}}+\beta_{3} \mathrm{EX}_{\mathrm{i}}^{2}+\mathrm{e}_{\mathrm{i}}
$$

Beside indications about training, other variables such as workplace characteristics, professional career, and personal traits of the worker should be included in the Mincer equation. These variables allow the research to identify the heterogeneity of each individual observed through the equations (Bartel, 1995).

$$
\mathrm{LnY}_{\mathrm{i}}=\beta_{0}+\alpha \mathrm{T}_{\mathrm{i}}+\beta_{1} \mathrm{~S}_{\mathrm{i}}+\beta_{2} \mathrm{EX}_{\mathrm{i}}+\beta_{3} \mathrm{EX}_{\mathrm{i}}^{2}+\beta_{4} \mathrm{X}_{\mathrm{i}}+\mathrm{e}_{\mathrm{i}}
$$

The Mincer equation shows that training plays a crucial role in workers' wages as well as the personality traits of trained workers. Wooldridge (2010) considers the correlation between training and personality traits, which enables to assess the impact of training on the wage of different worker groups. The average effectiveness of training in correlation with wages is varied by the different types of job, workplace, and others.

$$
\mathrm{LnY}_{\mathrm{i}}=\beta_{0}+\alpha \mathrm{T}_{\mathrm{i}}+\beta_{1} \mathrm{~S}_{\mathrm{i}}+\beta_{2} \mathrm{EX}_{\mathrm{i}}+\beta_{3} \mathrm{EX}_{\mathrm{i}}^{2}+\beta_{4} \mathrm{X}_{\mathrm{i}}+\delta \mathrm{T}_{\mathrm{i}} * \mathrm{X}_{\mathrm{i}}+\mathrm{e}_{\mathrm{i}}
$$

Heckman (1999) discovers that calculating salary equation based on a sample that contains only paid workers and excludes the unemployed, would render an unstable and deviated ordinary least squares (OLS). Heckman called this 'sample selection bias.'

According to Heckman's recommendation, correction of sample selection bias include 2 phases as below:

Phase 1: Regression of determinants on the participation in paid jobs using Probit model

Assuming T as a worker's wage, T' as the minimum wage that a worker accepts to work, the variation between wage and minimum wage is $\mathrm{T}^{*}=\mathrm{T}-\mathrm{T}^{\prime}$, and the worker will not go to work if his wage is smaller than the minimum wage or $\mathrm{T}^{*} \leq 0$.

Then $T^{*}$ is a latent variable model and explained as $T^{*}$ $=\beta \mathrm{Z}+\mathrm{u}$, where $\mathrm{Z}$ is a vector of personalities deciding if an 
individual has participated in training. $\mathrm{u}$ and $\rho$ are computed as $\mathrm{N}(0,1)$, and $\operatorname{corr}(\mathrm{e}, \mathrm{u})$, respectively.

Set the dummy variable $\mathrm{T}$ as below:

$\mathrm{T}=1$ if $\mathrm{T}^{*}>0$, go to work to earn wage.

$\mathrm{T}=0$ if $\mathrm{T}^{*} \leq 0$, don't go to work to earn wage.

If the research is based on the condition $\mathrm{T}^{*}>0$ or the sample is solely collected from paid workers, the wage equation measured for ethnic minority areas does not reflect the whole population of the areas. Workers are not going to work because they are paid lower than the minimum wage $T$ '. Neglecting the underpaid group will create a result that reflects the impact of independent variable on dependent one incorrectly.

The result in Phase 1 will lead to Mills variable, also referred to as the inverse of the Mills ratio (Heckman, 1999). Mills variable is controlled for phase 2 of the regression model.

Phase 2: the wage estimation equation for ethnic minority areas using the Mincer model is corrected by Heckman as below:

Lnwage $_{i}=\beta_{0}+\beta_{1}$ age $_{i}+\beta_{2}$ age $_{i}^{2}+\beta_{3}$ skill $_{i}+\beta_{4}$ skill $_{i}+$ $\beta_{5}$ Sex $_{\mathrm{i}}+\beta_{6}$ Rural $_{\mathrm{i}}+\beta_{8} \mathrm{FDI}_{\mathrm{i}}+\beta_{9}$ State $_{\mathrm{i}}+\beta_{10}$ ind $2_{\mathrm{i}}+\beta_{11}$ ind $_{\mathrm{i}}+$ $\beta_{12}$ ind $_{i}+\beta_{13}$ ind $5_{\mathrm{i}}+\beta_{14}$ ind $_{\mathrm{i}}+\beta_{15}$ ind $_{\mathrm{i}}+\beta_{16}$ Sex $_{\mathrm{i}}{ }^{\text {'Skill }} 2_{\mathrm{i}}+$ $\beta_{17} \operatorname{Sex}_{\mathrm{i}}{ }^{*} \operatorname{Skill}_{\mathrm{i}}+\beta_{18}$ Mills $_{\mathrm{i}}+\mathrm{e}_{\mathrm{i}}(*)$

In this equation, age and age 2 variables retrospectively stand for age and squared age of the worker and this is a proxy of experience variable. According to Mincer (1993), wage has a positive correlation with age variable but at a decreasing level as age increase.

Skills2 and Skill3 are variables for vocational training levels (skills2) and higher education levels (skill3). According to Becker (1964), Mincer (1993), Heckman (1999), Lynch (1992) and Blundell, et al. (1999), the higher human capital is revealed through educational levels, the greater the rate of return is, which leads to an assumption that trained workers will get better wages.

Sex: gender variable, equals to either 1, indicating male, or 0 , indicating female. There is an assumption that male workers have higher wage than female (Trostel et al., 2002; Jacobson et al., 2005).

In addition, the proposed model includes several control factors, such as (i) Rural dummy variable that receives value of 1 if the labor is in rural areas and 0 if the worker is in urban area. Rural dummy variable aims to distinguish wages between labor from rural areas and labor from urban areas; (ii) FDI variable that is used for the type of FDI ownership and state variable that is used for the type of state ownership in order to analyze the difference in wages of ethnic minority labor by ownership type; and (iii) Industry dummy variables (ind) that are also considered as control industry factors, e.g., ind2- Mining industry; ind3- Processing industry; ind4Construction industry; ind5- Hotel and restaurant industry; ind6- Transportation, warehousing, communications industry; ind7- Other industries.

The model $(*)$ uses a variable that accounts for the interaction between the gender variable and vocationally trained labor (Skill2) and the trained labor from college or university or higher (Skill3) to analyze how the impact of trained labor on wages varies by gender.

\subsection{Data}

This study uses VHLSS, which is conducted every two years by GSO. The total number of samples is 106,556, collected in the last three periods, i.e., 35,920 people in 2014, 35,640 people in 2016 and 34,996 people in 2018. This is the national survey using extrapolation weights. This study employs key information, including the demographic characteristics of workers, their education, training process, jobs, and wages.

In order to analyze the impact of vocational training on wages of ethnic minority areas in Vietnam, this research creates ethnic area variables. According to Vietnamese regulations, ethnic areas are communes of 51 different provinces (out of 63 provinces in Vietnam), which are inhabited by ethnic minority people. The statistics from VHLSS in 2018, show that the proportion of labors of working age (from 15 to 55 years old for women and from 15 to 60 years old for men) with a certificate was $22.5 \%$, an increase of about 2.5 percentage points as compared to 2014 .

In ethnic minority areas, the percentage of trained labor were $20.1 \%$ in 2018 and $17.6 \%$ in 2014; and the proportion of trained labor of working age is quite low, about $8.1 \%$ (8.1\% in 2014 and $8.13 \%$ in 2018).

For wage labor, the proportion of trained labor was 30\% in 2014 and $32.7 \%$ in 2018 and the proportion of vocationally trained labor was $11.7 \%$ in 2014 and $11.4 \%$ in 2018.

The average wage of ethnic minority labor increased from VND3.5 million (e8.18) in 2014 to VN5.0 million (e8.52) in 2018 , an average annual increase of $8.8 \%$. This average wage of ethnic minority labor is lower than the average country wage, which was VND4.3 million/month in 2014 and VND6.4 million/month in 2018, respectively (see Table 1). The currency in Vietnam is Vietnamese dong (or VND).

The lnwage dependent variable over the years is described as the logarithmic density of wages as shown in Figure 1. The wage density function of 2014, 2016 and 2018 is calculated based on the data of the labor group, which has information on wages, in working age and in ethnic minority areas. The actual wage density function of 2018 moves to the right as compared to 2014, showing that the average wage in 2018 was higher than that in 2014. 
Table 1: Description of the variables employed in the wage model

\begin{tabular}{|l|c|c|c|c|c|c|}
\hline & \multicolumn{2}{|c|}{ From 2014 to 2018 } & \multicolumn{2}{c|}{ 2018 } & \multicolumn{2}{c|}{ 2014 } \\
\hline \multicolumn{1}{|c|}{ Variables } & Mean & Std. Dev. & Mean & Std. Dev. & Mean & Std. Dev. \\
\hline Inwage & 8.34 & 0.63 & 8.52 & 0.65 & 8.18 & 0.61 \\
\hline age & 35.65 & 10.83 & 35.95 & 10.67 & 35.33 & 10.87 \\
\hline age2 & 1388 & 805 & 1406 & 797 & 1366 & 802 \\
\hline skill2 & 0.12 & 0.32 & 0.11 & 0.32 & 0.12 & 0.32 \\
\hline skill3 & 0.20 & 0.40 & 0.21 & 0.41 & 0.18 & 0.39 \\
\hline sex & 0.60 & 0.49 & 0.59 & 0.49 & 0.61 & 0.49 \\
\hline sex_skill2 & 0.08 & 0.27 & 0.08 & 0.28 & 0.08 & 0.27 \\
\hline sex_skill3 & 0.09 & 0.29 & 0.10 & 0.30 & 0.09 & 0.28 \\
\hline rural & 0.64 & 0.48 & 0.64 & 0.48 & 0.65 & 0.48 \\
\hline Industry & & & & & & 0.11 \\
\hline Ind2 & 0.01 & 0.11 & 0.01 & 0.10 & 0.01 & 0.11 \\
\hline Ind3 & 0.20 & 0.40 & 0.22 & 0.41 & 0.19 & 0.39 \\
\hline Ind4 & 0.01 & 0.07 & 0.00 & 0.07 & 0.01 & 0.08 \\
\hline Ind5 & 0.01 & 0.07 & 0.00 & 0.06 & 0.01 & 0.09 \\
\hline Ind6 & 0.13 & 0.34 & 0.14 & 0.35 & 0.13 & 0.34 \\
\hline Ind7 & 0.35 & 0.48 & 0.37 & 0.48 & 0.34 & 0.47 \\
\hline Sector & & & & & & \\
\hline state & 0.20 & 0.40 & 0.19 & 0.39 & 0.22 & 0.41 \\
\hline fdi & 0.08 & 0.27 & 0.09 & 0.29 & 0.07 & 0.25 \\
\hline
\end{tabular}

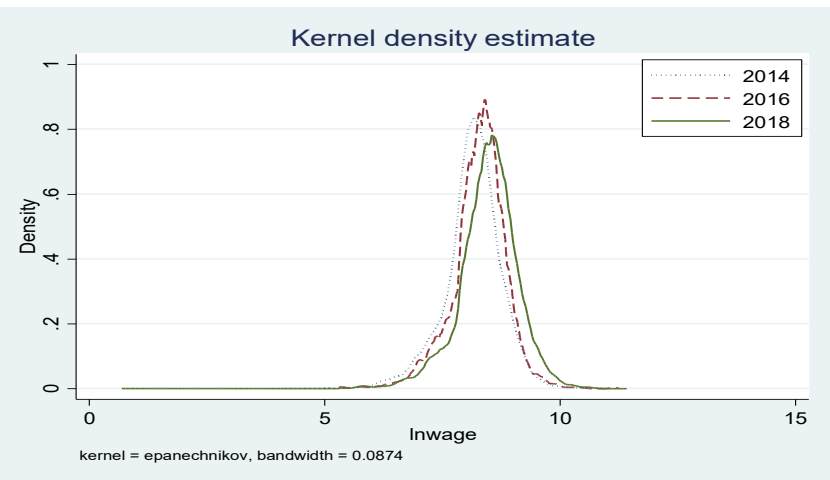

Figure 1: Kernel density estimation

\section{Results and Discussion}

It has been observed that implementing vocational training policies for ethnic minorities can potentially lead to an increase in the number of workers that receive vocational training support. This also create a transformation from capacity-based teaching into market demand-oriented training in vocational schools. Most workers recognize the necessity and objectives of VET. Their motivation has changed from social learning influence, learning for receiving food support to learning for making a living, finding a job and improving productivity.

Apart from the achieved outcomes, vocational training and job creation for ethnic minorities are not without limitations and shortcomings. For instance, the number of ethnic minority workers taking part in VET is still low (approximately 14\% of the total number of ethnic minorities in working age). Most of them just participate in short-term classes of less than three months with the focus on agriculture. In addition, the effectiveness of vocational training in some places is not as high as expected. Many workers have jobs that are not in line with the training. Meanwhile, organizing classes for ethnic minorities also face many difficulties due to unfavorable traffic conditions. The way of organizing these classes is not suitable for current production, cultural, and geographical practices in mountainous and remote areas, and hence, failing to attract ethnic minorities. These shortcomings are due to the following facts: 
First, the qualifications of ethnic minorities are uneven. There is a group of older ethnic minorities who has limited ability to learn new skills. These people are hesitant to either go to school or actively seek a job.

Second, common thinking in ethnic minorities is that vocational training is time-consuming; taking the course would cause them to lose their current job. Due to communal living habits and hesitation to change the living environments, ethnic minorities do not fully understand the importance of vocational training.

Third, in many localities, the task of mobilizing ethnic minorities to learn vocational skills, to support for job search, to guide on training loans and product sales support has not been the focus. The method of organizing mobilization is neither creative, nor effective. Therefore, ethnic minorities have not realized the benefits of vocational training and hence, are not actively participating in the training programs.

Fourth, local authorities at all levels and responsible agencies are not paying enough attention to vocational training for ethnic minorities. For this reason, there is a lack of vocational training integration in local socio-economic development policies and plans.

Although the results of the implementation of vocational training policies for mountainous and rural areas still face shortcomings, it has contributed to the improvement of wages for ethnic minority workers.

Table 2 shows the results of estimating the impact of training on the wage of ethnic minority labors from both VHLSS data and the method mentioned above. The athrho and lnsigma coefficients are significant at 99\% confidence level, which confirms the existence of sampling bias. Thus, the Heckman estimation model is perfectly suitable.

The group without a certificate is set as the base variable when comparing the dummy variables. Vocational training variables are expressed through skill2 dummy variables in the model. College and university training are shown through skill3 variables. The estimated results of these variables are statistically significant.

On average, from 2014 to 2018, the group of labor who graduated from college, university or even higher had higher average wage than the untrained group labor $\left(\mathrm{e}^{0,617}-\right.$ $1) * 100 \%=85,5 \%$. The group with vocational training had the average wage higher than the group without training $\left(\mathrm{e}^{0,339}\right.$ $-1)^{*} 100 \%=40,4 \%$, which means that the more technically qualified labor, the higher the wage. The wage gap between the vocational training group and the untrained group tends to reduce from $53,9 \%\left(=\left(\mathrm{e}^{0,431}-1\right) * 100 \%\right)$ in 2014 to $30,1 \%$ $\left(=\left(\mathrm{e}^{0,263}-1\right)^{*} 100 \%\right)$ in 2018 . However, this observation is not valid when considering the relation between the college, university or higher graduated group and the untrained group. The wage gap between these two groups tends to enlarge, from $\left.83,9 \%\left(=\mathrm{e}^{0,609}-1\right)^{*} 100 \%\right)$ in 2014 to $90,2 \%$ $\left.\left(=\mathrm{e}^{0,643}-1\right) * 100 \%\right)$ in 2018 (see Figure 2).
The estimation results also show that in ethnic minority areas, the average wage of male labor is higher than that of female labor $\left(\mathrm{e}^{0.202}-1\right) * 100 \%=22,4 \%$. The difference in wages between male and female labor in ethnic minority areas tended to decrease, from $25,9 \%\left(=\left(\mathrm{e}^{0.230}-1\right)^{*} 100 \%\right)$ in 2014 to $22.4 \%$ in 2018 .

The result of the interaction variable between sex and skill2 variables is negative, showing that in ethnic minority areas (see Table 2), if labors are at the same level of vocational training, the wage of male is lower than that of female. However, this trend changed in 2018, where the wages of trained male labor were higher than those of untrained female labor. Besides, the above model also shows that ethnic minority labors working in foreign direct investment (FDI) sector have higher wages than those in public and non-state sectors (about $39.4 \%$ higher $\left(=\left(\mathrm{e}^{0.332}-\right.\right.$ $1)^{*} 100 \%$ ); ethnic minority labors working in rural areas have lower wages than those in urban areas (about 16.5\% lower).

Thus, it can be seen that the results of estimating the impact of vocationally trained labor on wages of ethnic minority labors are consistent with the Human Capital Theory (Becker, 1964). Labors who are trained will have a positive impact on their productivity and wage growth. A similar observation can be found in Becker (1964), Mincer (1993), Heckman (1999), Fanz (2003), Lynch (1992) and Blundell et al. (1999).

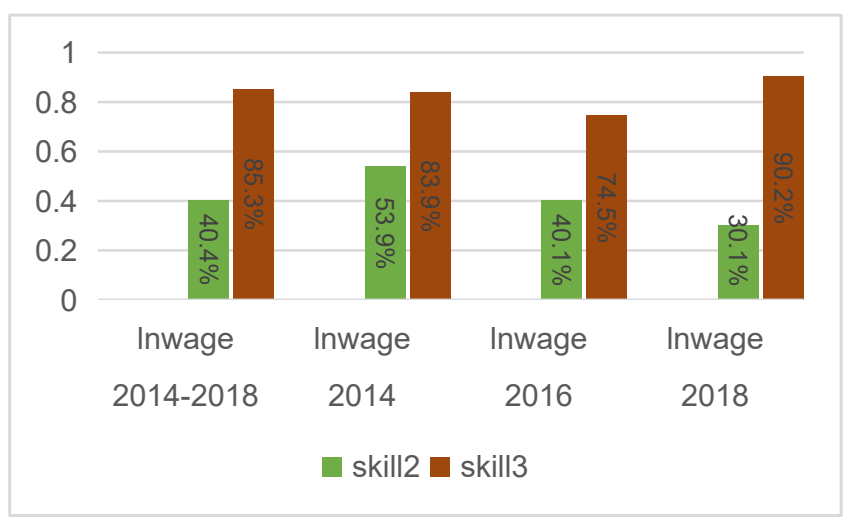

Figure 2: The magnitude of the impact of training and vocational training on wages

\section{Conclusions}

The discussion of results from the quantitative model shows that ethnic minority labors who received vocational training and tertiary training have an impact on wage growth. However, professional and highly technical labors have higher productivity (Budria \& Telhado-Pereira, 2009). Therefore, the low technical qualification that ethnic minority labors within working age possess (the proportion of trained labors was $8.13 \%$ in 2018) leads to lower wages. 
Table 2: Results of analysis of the impact of vocational training on wages

\begin{tabular}{|c|c|c|c|c|}
\hline & From 2014 to 2018 & 2014 & 2016 & 2018 \\
\hline Variables & Inwage & Inwage & Inwage & Inwage \\
\hline \multirow[t]{2}{*}{ age } & $0.048^{*+2 t}$ & $0.041^{\text {tat }}$ & $0.041^{\text {t*t }}$ & $0.054^{* *+x}$ \\
\hline & $(0.000)$ & $(0.000)$ & $(0.000)$ & $(0.000)$ \\
\hline \multirow[t]{2}{*}{ age2 } & $-0.001^{* * *}$ & $-0.000^{* * *+}$ & $-0.000^{* * *}$ & $-0.001^{*+*}$ \\
\hline & $(0.000)$ & $(0.000)$ & $(0.000)$ & $(0.000)$ \\
\hline \multirow[t]{2}{*}{ skill2 } & $0.339^{*+* t}$ & $0.431^{n+4}$ & $0.337^{*+*}$ & $0.263^{*+*+x}$ \\
\hline & $(0.001)$ & $(0.001)$ & $(0.001)$ & $(0.001)$ \\
\hline \multirow[t]{2}{*}{ skill3 } & $0.617^{*+2}$ & $0.609^{*+*+}$ & $0.557^{*+*}$ & $0.643^{*+* x}$ \\
\hline & $(0.000)$ & $(0.001)$ & $(0.001)$ & $(0.001)$ \\
\hline \multirow[t]{2}{*}{$\operatorname{sex}$} & $0.202^{*+2+x}$ & $0.230^{n+*}$ & $0.207^{*+*}$ & $0.202^{*+*+}$ \\
\hline & $(0.000)$ & $(0.000)$ & $(0.000)$ & $(0.000)$ \\
\hline \multirow[t]{2}{*}{ sex_skill2 } & $-0.059^{*+*}$ & $-0.179^{* *+x}$ & $-0.083^{*+*+}$ & $0.028^{* *+x}$ \\
\hline & $(0.001)$ & $(0.001)$ & $(0.001)$ & $(0.001)$ \\
\hline \multirow[t]{2}{*}{ sex_skill3 } & $-0.050^{* * *+}$ & $-0.046^{* * t+}$ & $-0.095^{* * *}$ & $-0.037^{*+1}$ \\
\hline & $(0.000)$ & $(0.001)$ & $(0.001)$ & $(0.001)$ \\
\hline \multirow[t]{2}{*}{ rural } & $-0.180^{+* *+}$ & $-0.187^{+* *+}$ & $-0.171^{t+4}$ & $-0.209^{*+*}$ \\
\hline & $(0.000)$ & $(0.000)$ & $(0.000)$ & $(0.000)$ \\
\hline \multirow[t]{2}{*}{ Ind2 } & $0.398^{*+* t}$ & $0.288^{*+1+}$ & $0.435^{\text {tat }}$ & $0.422^{*+*+x}$ \\
\hline & $(0.001)$ & $(0.001)$ & $(0.001)$ & $(0.002)$ \\
\hline \multirow[t]{2}{*}{ Ind3 } & $0.359^{*+*}$ & $0.289^{*+*}$ & $0.351^{1+*}$ & $0.395^{*+* x}$ \\
\hline & $(0.000)$ & $(0.001)$ & $(0.001)$ & $(0.001)$ \\
\hline \multirow[t]{2}{*}{ Ind4 } & $0.343^{*+*}$ & $0.284^{*+*+}$ & $0.434^{*+*}$ & $0.265^{* *+x}$ \\
\hline & $(0.001)$ & $(0.002)$ & $(0.002)$ & $(0.002)$ \\
\hline \multirow[t]{2}{*}{ Ind5 } & $0.224^{*+*}$ & $0.133^{* * *}$ & $0.208^{*+*}$ & $0.384^{x+x+x}$ \\
\hline & $(0.001)$ & $(0.002)$ & $(0.002)$ & $(0.002)$ \\
\hline \multirow[t]{2}{*}{ Ind6 } & $0.328^{*+* t}$ & $0.285^{+* t+}$ & $0.319^{*+*+}$ & $0.347^{\text {tat }}$ \\
\hline & $(0.000)$ & $(0.001)$ & $(0.001)$ & $(0.001)$ \\
\hline \multirow[t]{2}{*}{ Ind7 } & $0.281^{*+*}$ & $0.216^{*+*}$ & $0.266^{*+*+}$ & $0.291^{* * * x}$ \\
\hline & $(0.000)$ & $(0.001)$ & $(0.001)$ & $(0.001)$ \\
\hline \multirow[t]{2}{*}{ state } & $-0.101^{* * t+}$ & $0.002^{+*+t}$ & $-0.091^{t+4 t}$ & $-0.118^{*+*+1}$ \\
\hline & $(0.000)$ & $(0.000)$ & $(0.000)$ & $(0.000)$ \\
\hline \multirow[t]{2}{*}{ fdi } & $0.332^{* * * *}$ & $0.364^{* * *+}$ & $0.296^{*+*}$ & $0.313^{*+* x}$ \\
\hline & $(0.000)$ & $(0.001)$ & $(0.001)$ & $(0.001)$ \\
\hline \multirow[t]{2}{*}{ athrho } & $0.049^{*+*}$ & $0.039^{*+*}$ & $-0.066^{* * *+}$ & $0.119^{*+* t}$ \\
\hline & $(0.001)$ & $(0.002)$ & $(0.003)$ & $(0.002)$ \\
\hline \multirow[t]{2}{*}{ Insigma } & $-0.645^{*+*}$ & $-0.699^{* * *+}$ & $-0.729^{* * * *}$ & $-0.625^{*+*}$ \\
\hline & $(0.000)$ & $(0.000)$ & $(0.000)$ & $(0.000)$ \\
\hline \multirow[t]{2}{*}{ Constant } & $6.933^{*+*}$ & $6.923^{\text {tw+ }}$ & $7.083^{\text {w+*t+ }}$ & $6.989^{*+* x}$ \\
\hline & $(0.001)$ & $(0.002)$ & $(0.002)$ & $(0.002)$ \\
\hline Obs & 15,720 & 5,255 & 5,233 & 5,232 \\
\hline
\end{tabular}

Note: Standard errors in parentheses ${ }^{* * *} p<0.01,{ }^{* *} p<0.05,{ }^{*} p<0.1$ 
The results of this study provide evidence that vocationally-trained labors working in ethnic minority areas bring higher wage opportunities than non-vocationallytrained labors do. Especially with the same vocational training level, male labors had lower wages compared to female labors in 2014-2018. This may be due to the characteristics of the ethnic minority regions in Vietnam. Male labors often prefer temporary jobs, while female labors are more likely to work permanently and more willing to work in factories. In addition, female labors tend to achieve job requirements and skills quickly and easily through training (Budria \& TelhadoPereira, 2009). However, in 2018, the trend of the impact of vocationally trained workers was different between men and women.

On the other hand, it is possible that the content of vocational training in ethnic minority areas has not met the market demand, which leads to labors not willingly promote the effectiveness of training programs. Thus, with the characteristics of ethnic minority areas: difficult natural conditions and low socio-economic development levels, vocational training for labors that associates with regional practices will be more effective.

The results of this study provide several recommendations in order to encourage participation in vocational training for the purpose of promoting the efficiency of the labor market:

First, to labors: Labors need to recognize the importance of learning and to improve themselves in order to have better job opportunities and higher wages. However, the training certificate is meaningful only if it is relevant to individual's competencies and market's demands. Therefore, labors need to choose a suitable career;

Second, to enterprises: Creating opportunities to improve the qualifications of labors will contribute to higher productivity and competitiveness of enterprises. Also, the enterprises should cooperate with training institutions to develop training content and to provide vocational training and support for labors in practical activities;

Third, to the Government: There should be specific policies supporting vocational-training service providers to organize vocational training for ethnic minority labors. The government also needs to develop training contents that are consistent with the situation of economic development in ethnic minority areas and suitable for local demands.

\section{The specific solutions below need to be considered and implemented:}

First, being more proactive in developing vocational training plans and allocating resources for vocational training to ensure adequate and timely support for ethnic minority workers who would like to participate in apprenticeship; completing policies that reduce tuition fee completely and increase scholarships, accommodation and travel support for vocational ethnic minorities with difficult circumstances; developing mechanisms to link vocational training with job creation, and thus motivate ethnic minority workers to participate actively in vocational training through specific credit support policies for trainees.

Second, prioritizing investment in material facilities for key schools in ethnic minority areas. Prioritizing funding to support rural labor taking part in vocational training with large ethnic minority populations; training vocational teachers at vocational training institutions; developing preferential and higher remuneration policies to attract talented and competent teachers, artisans and advanced craftsmen to participate in vocational training for ethnic minorities for better training quality.

Third, strengthening the network of vocational training institutions and training occupations by region and locality; focusing on building specialized vocational training institutions/traditional jobs for ethnic areas that are best suited to the conditions and the needs of socio-economic development of each region, especially in mountainous areas; building an appropriate vocational training model, local job identity based on local socio-economic development condition, culture, customs and qualification of ethnic minority workers; reforming vocational training programs in accordance with current market demand and qualifications of ethnic minority participants; developing programs based on skill requirements of specific job and designing specialized training programs in ethnic languages for some ethnic minorities in mountainous areas that is suited to the conditions and the circumstances of these target groups; reviewing and selecting portfolio of training occupations for ethnic minorities in addition to traditional occupations that focus on the requirements of high-tech agriculture in the current period; restructuring the agricultural sector. Non-agricultural vocational training must originate from the needs of enterprises, industrial parks, manufacturing areas, large projects and labor export. Regularly updating the list of occupations, training programs, and formulating appropriate cost structure for certain types of job to attract people to register for vocational training and to improve production efficiency in their localities.

Fourth, building close relationships between vocational education and labor market in regions and localities from districts and communes upwards to ensure that the operation of the vocational education system aims at meeting employers' needs, thus creating jobs for ethnic minorities after apprenticeship; implementing preferential policies for enterprises to invest in mountainous and ethnic minority areas; encouraging enterprises, economic sectors and nonpublic vocational training institutions to participate in vocational training and employ ethnic minorities to work for enterprises; diversifying forms and methods of organizing vocational training classes so that ethnic minority can strengthen their skills and apply their knowledge in the 
production process; developing mechanisms to promote active participation of employers and workers. At the same time, it is necessary to firmly understand the labor's needs for each profession and field based on branch and sector development plans; encouraging enterprises and good farmers to identify demands, organize vocational training and consume commodity products. This way, the new training and vocational training would be more effective for rural workers, especially ethnic minorities in mountainous areas.

Fifth, enhancing knowledge and information preparation for officials at all levels, party members, and local authority officials such as village and commune heads, village elders and village heads, who have strong influence on ethnic minority communities in each area regarding the content and importance of the Party's guidelines and resolutions on the development of ethnic minority human resources; ensuring that propaganda officers are knowledgeable about policies and provides adequate, timely information for ethnic workers on vocational training and job creation policies after apprenticeship so that they can promote their abilities, skills, awareness, responsibility in learning, contributing to improving the quality of training; improving the propaganda and vocational training counseling in various forms; integrating them with community cultural activities so that ethnic minorities can easily access, gain information, knowledge, and benefits from participating in vocational training; promoting and encouraging ethnic youth to participate in longer-term training courses in order to improve their capacity and find better jobs.

\section{References}

Andren, T. \& Andren, D. (2006). Assessing the Employment Effects of Vocational Training using a One-factor Model. Applied Economics Journal, 38, 2469-2486. https://doi. org/10.1080/00036840500427577

Ashenfelter, O., Harmon, C. \& Oosterbeek, H. (1999). A Review of Estimates of the Schooling/Earnings Relationship, with Tests for Publication Bias. Journal of Labour Economics, 6, 453-470. https://doi.org/10.1016/S0927-5371(99)00041-X

Bartel, A. P. (1995). Training, Wage Growth, and Job Performance: Evidence from a Company Database. Journal of Labor Economics, 13(3), 401-425. https://doi.org/10.1086/298380

Bartlett, W. (2009). The Effectiveness of Vocational Education in Promoting Equity and Occupational Mobility Amongst Young People. Economic Annals, 54(180), 7-39. https://doi. org/10.2298/EKA0980007B

Becker, G. (1964). Human Capital: A Theoretical and Empirical Analysis with Special Reference to Education. New York, NY: Columbia University Press. https://doi. org/10.1177/000271626536000153
Blundell, R., Dearden, L., Meghir, C., \& Sianesi, B. (1999). Human Capital Investment: The Returns from Education and Training to the Individual, the Firm and the Economy. Fiscal Studies, 20(1), 1-23. https://doi.org/10.1111/j.1475-5890.1999. tb00001.x

Budria, S., \& Telhado-Pereira, P. (2009). The Contribution of Vocational Training to Employment, Job-related Skills and Productivity: Evidence from Madeira Island. International Journal of Training and Development 13(1), 53-72. https://doi. org/10.1111/j.1468-2419.2008.00315.x

Choi, S., (2016). Effects of Vocational Education on Wage: Case of Philippines. Journal of Economics and Sustainable Development, 7(10), 27-51. Retrieved May 28, 2019, from https://iiste.org/Journals/index.php/JEDS/article/ view/30844/31695

Dearden, L., McIntosh, S., Myck, M. \& Vignoles, A. (2002). The Returns to Academic and Vocational Qualifications in Britain. Bulletin of Economic Research, 54(3), 249-274. https://doi. org/10.1111/1467-8586.00152

Heckman, J. (1999). Policies to Foster Human Capital. NBER Working Paper, No. 7288, Cambridge. https://doi.org/10.3386/ w7288

Hujer, R., Thomsen, S. L. \& Zeiss, C. (2006). The Effects of Vocational Training Programmes on the Duration of Unemployment in Eastern Germany. Allgemeines Statistisches Archive, 90, 299321. https://doi.org/10.1007/s10182-006-0235-z

Jacobson, L., LaLonde, R. \& Sullivan, D. (2005). Estimating the Returns to Community College Schooling for Displaced Workers. Journal of Econometrics, 125(1-2), 271-304. https:// doi.org/10.1016/j.jeconom.2004.04.010

Kireyeva, A. A., \& Satybaldin, A. A. (2019). Analysis of Gender Pay Gap in Different Sectors of the Economy in Kazakhstan. Journal of Asian Finance, Economics and Business, 6(2), 231238. https://doi.org/10.13106/jafeb.2019.vol6.no2.231

Lynch, L. (1992). Private-Sector Training and the Earnings of Young Workers. The American Economic Review, 82(1), 299312. Retrieved April 19, 2019, from https://www.jstor.org/ stable/2117617

Maliranta, M., Rouvinen, P. \& Ylä-Anttila, P. (2010). Finland's Path to the Global Productivity Frontiers through Creative Destruction. International Productivity Monitor, 20, 68-84. Retrieved June 24, 2019, from http://www.csls.ca/ipm/20/IPM20-Maliranta-Rouvinen-Yla-Anttila.pdf

Meer, J. (2007). Evidence on the Returns to Secondary Vocational Education. Economics of Education Review, 26, 559-573. https://doi.org/10.1016/j.econedurev.2006.04.002

Mincer, J. (1993). Studies in Human Capital. Hampshire, England: Edward Elgar Publishing Limited. ISBN: 9781852785796

Mincer, J. A. (1974). Schooling, Experience, and Earnings. New York, USA: National Bureau of Economic Research and Columbia University Press. ISBN: 9780870142659

Nguyen, H. H., \& Nguyen, N. V. (2019). Factor affecting poverty and policy implication of poverty reduction: A case study for the 
Khmer ethnic people in Tra Vinh Province, Viet Nam. Journal of Asian Finance, Economics and Business, 6(1), 315-319. http://doi.org/10.13106/jafeb.2019.vol6.no1.315

Nguyen, T. T. H., Nguyen, T. T. H., Nguyen, T. L. H., \& Nguyen, V. C. (2020). The Impact of International Integration on the Inequality of Income between Rural and Urban Areas in Vietnam. Journal of Asian Finance, Economics and Business, 7(3), 277-287. https://doi.org/10.13106/jafeb.2020. vol7.no3.277

Oosterbeek, H. \& Webbink, D. (2007). Wage Effects of an Extra Year of Basic Vocational Education. Economics of Education Review, 26, 408-419. https://doi.org/10.1016/j. econedurev.2006.07.013

Sala, H. \& Silva, J. I. (2013). Labor Productivity and Vocational Training: Evidence from Europe, Journal of Productivity Analysis. 40(1), 31-41. https://doi.org/10.1007/s11123-0120304-0
Stromback, T. (2010). Earnings, Schooling and Vocational Education and Training. Australian Journal of Labour Economics, 13(3), 241-263. Retrieved May 10, 2019, from https:/espace.curtin.edu.au/bitstream/ handle/20.500.11937/47210/154198_30840_299stromback. pdf? sequence $=2 \&$ isAllowed $=y$

Tansel, A. \& Bodur, F. B. (2012). Wage Inequality and Returns to Education in Turkey: a Quantile Regression Analysis. Review of Development Economics, 16(1), 107-121. https://doi. org/10.1111/j.1467-9361.2011.00655.x

Trostel, P., Walker, I. \& Wolley, P. (2002). Estimates of the Economic Return to Schooling for 28 Countries. Labour Economics, 9(1), 1-16. https://doi.org/10.1016/S0927-5371(01)00052-5

Wooldridge, J. (2010). Econometric Analysis of Cross Section and Panel Data ( $2^{\text {nd }}$ ed.). Cambridge, MA: The MIT Press. 